\title{
Appendix: Question Types Questionnaire
}

\author{
Cédric Patin
}

Savoirs, Textes, Langage (Université Lille 3 - CNRS UMR 8163)

\section{Kristina Riedel}

ZAS, Berlin

This questionnaire is intended as an aid to eliciting different question types, including yes/no questions, alternative questions, and wh-questions on a range of constituents. We have taken care to include examples that allow one to test for common Bantu phenomena, such as a subject/non-subject asymmetry in whquestions and an obligatory immediately after the verb (IAV) position for questioning verb complements. The questionnaire is intended as a guide, only, as every language will have its own set of possibilities and complications. At the end of the questionnaire is a checklist. While we had Bantu languages in mind in devising the questionnaire, we hope it will also be useful to linguists with an interest question constructions in other languages.

\section{Overview}

Comparison of question types covered in the questionnaire:
a. What do you want to drink? (Wh-question)
b. Do you want coffee? (Yes/no question)
c. Do you want coffee or tea? (alternative question)/ with yes/no answer
d. You want what? (echo question)
e. You want coffee, don't you? (tag question)
f. Say, do you want coffee? (question with an initial-question particle)
g. Which drink do you want? (which-question)
h. What drink do you want? (what NP question) 


\section{2 (Simple) wh-questions}

\subsection{Subject}

(1) Who saw Juma? Ali saw him.

(2) What happened? There was a fire.

(3) Who arrived late? Mary arrived late.

(4) Who wants more cake? All of the children want more cake.

(5) Who will buy the food? Father will buy the food.

(6) What damaged the bridge? An overloaded truck.

(7) Who has fallen asleep? The baby has fallen asleep.

(8) Who didn't help to clean? Father didn't help.

(9) What caused that wound? A dog bit me.

(10) Who doesn't eat cake? My aunt because she is a diabetic.

(11) Who arrived there first? I did. (expletive?)

(12) Who lives there? John lives there. (expletive?)

\subsection{Object}

(13) What did Juma get for Eid /Christmas? A blue shirt.

(14) Who did you meet at the movies? My cousin.

(15) What did you (pl.) see in London? We saw Big Ben and the Tower of London.

(16) What has Salma brought for father? Today's newspaper.

(17) Who don't you like? I don't like my Kiswahili teacher.

(18) What will you eat for dinner? We will eat rice and meat for dinner.

(19) What is Hamisi reading to father? Hamisi is reading the newspaper to father.

(20) Who pl. did you see at the market this morning? I saw my friends at the market this morning.

(21) What don't you like about the book? The main character is too mean.

\subsection{Double Object Construction (DOC) Indirect Object (IO)}

(22) Who did you give the oranges to? I gave the oranges to my neighbor.

(23) For whom is Mary buying the book? She is buying the book for her friend.

(24) Who are you baking the cake for? We are baking the cake for the children.

(25) For what are you buying the food? We are buying the food for the party.

(26) Who will she teach French to? She will teach French to the neighbour's daughter.

(27) Whom haven't you given any cake yet? The people sitting in the back. 


\section{$2.4 \quad$ DOC Direct Object (DO)}

(28) What did you give your sister? I gave my sister some fruit from Lushoto.

(29) What is he teaching the students? He is teaching the students mathematics.

(30) What will you show the visitors? I will show the visitors the market and the university.

(31) What did you forget to buy for your sister? I forgot to buy my sister the English textbook.

(32) Which story haven't you read to this child yet? The one with the lion.

\subsection{Reciprocal verbs (potentially, depending on the language)}

(33) Who did we talk to? We talked to my mother.

(34) Who will she go there with? She will go there with my neighbour.

(35) Who haven't you met yet? I haven't yet met the lady standing in the corner.

(36) Who did the students argue with? They argued with their English teacher.

\subsection{Locative}

(37) Where was the President born? He is from Bagamoyo.

(38) Where are you (pl.) going? We are going to school.

(39) Where did Mary get this book? She got this book in the capital.

(40) Where are you thinking of building a house? I want to build a house in my home village.

(41) Where wouldn't you agree to move? I would not like to work in a big city.

(42) Where will you (pl.) send the children to school? We will send the children to school in Blantyre.

\subsection{Temporal}

(43) When are you going on vacation? We are going on vacation in June.

(44) What time did she arrive? She arrived at 8am.

(45) When will the rains start? Probably next month.

(46) What time do you want to meet? Let's meet at 3pm.

(47) When did you see Mary? I saw Mary yesterday. 


\subsection{Manner/Instrumental}

(48) How did you (pl.) get here? We came by bus.

(49) How does Mary make her chocolate cake? She makes her cake with grated chocolate and cinnamon.

(50) How will they dance at the wedding? They will dance in the traditional style.

(51) How did he find out (that they were talking about him like this)? He caught them.

(52) How did Mary fix the car? She fixed the car with the tools that were in the boot.

(53) How is she chopping (cutting) the firewood? She is chopping firewood with an axe.

\subsection{Why/Reason}

(54) Why is it always so hot in March? Because of the humidity.

(55) Why did the teacher not set any homework? Because tomorrow is a national holiday.

(56) Why will you not go home for Christmas? Because I can't afford too.

(57) What did you give her the money for? To pay her brother's school fees.

(58) What are they inviting us for? It's a wedding.

\subsection{How come (negative/surprise question)}

(59) How come the children are already at home? There was no school today.

(60) How come you didn't buy milk? There was none.

(61) How come we are eating cabbage again? There is so much of it in the garden.

\section{Which-questions/what-questions/how many}

(62) Which neighbour saw Juma? Ali saw him.

(63) Which student arrived late? All of them arrived late.

(64) Which children want cake? Mary and Sue want cake.

(65) Which adult will buy the food? Father will buy the food.

(66) Which child has fallen asleep? Mary's son has fallen asleep.

(67) Which of these books are you ordering? The entire list.

(68) What time is the lecture? In the morning.

(69) Which book do you want? I want the blue one.

(70) Which book did you give your mother? I gave her the dictionary.

(71) Which child did you make write on the board? Mary. 
(72) Which friend did you drive home? John.

(73) Which boyfriend will she introduce to her parents? Maybe neither of them.

(74) What sights did you show them? The Zomba plateau and the national park.

(75) What name did they chose? They preferred Jane in the end.

(76) What place did you take them to? My mother's house.

(77) What shirt did you lend him? The green one.

(78) How many guests are invited? Twenty-five guests are invited.

(79) How many days are you staying there? Only three.

(80) How much water is left? Two large buckets.

(81) How many children do you want to have? Two, I think.

(82) Which guy did she marry? The banker? No, the teacher.

\section{Yes/no-questions}

(83) Does Juma want cake? Yes, he does.

(84) Did you buy the book? No, they didn't have it.

(85) Will you come back tomorrow? Yes.

(86) Do you think she is ready? Probably.

(87) Have you seen him? Not yet.

(88) Do you like the decorations? Yes, they are beautiful.

(89) Have you ever been to London? Not yet.

(90) Do you know why she came here? No, I have no idea.

\section{Either/or questions}

(91) Do you want a donut or a proper lunch? Lunch, I am hungry.

(92) Do you prefer the large one or the small one? I think the small one is more practical.

(93) Did he choose the job at the bank or with the big company? He chose the job at the bank.

(94) Does he want tea or coffee? Yes, please give him some hot water.

(95) Do you own or rent a house? No, I live with my parents.

(96) Did she go to church or mosque there? No, she is a Hindu.

\section{Echo questions}

(97) A: I like bananas. B: You like what? A: I said I like bananas.

(98) A: John is coming tomorrow. B: Who will come tomorrow? A: I said John will come tomorrow. 
(99) A: They will come at 7pm. B: What time will they come? A: I said at $7 \mathrm{pm}$.

(100) A: They are running late. Their car has broken down. B: Why are they late? A: I saidthat their car has broken down.

(101) A: I live up in the hills. B: Where do you live? A: I said up in the hills.

\section{$7 \quad$ Rhetorical questions}

(102) A: Are you free tomorrow? Am I free tomorrow?! I have a million things to get done.

(103) A: Will they ever stop corruption? I just know they won’t.

(104) A: Will this road ever be finished? I no longer believe it.

(105) A: Why don't you listen to me? It's driving me mad.

(106) Who would agree to go so far away? No one!

(107) Who would be able to afford to educate all these children? No one! There are too many of them!

(108) Who would touch a wild crocodile? No one! You/one would have to be crazy.

(109) Who said that it would be easy to do that? No one!

(110) What can they tell him? Nothing! No one can solve his problem.

(111) What are they going to do for him? Nothing! No one can solve his problem.

(112) What will she offer him? Nothing! She is so selfish/mean.

(113) Where will they find another teacher? Nowhere! No one wants to go to this village.

(114) Where will she meet such a brave man? Nowhere! Such a man doesn't exist.

(115) To whom will they sell such an ugly cow? No one! Nobody will buy it!

(116) Why would I do such a stupid thing?

(117) Why would I say that?

(118) When will this plane arrive? Never! These flights are always being cancelled!

(119) What has he ever done for you? And you keep helping him.

\section{Surprise questions}

(120) A: I bought it. B: You did WHAT? But it was ridiculously expensive.

(121) A: He sold the house. B: He did WHAT? How could he do that?

(122) A: I won the lottery. B: You what? That's amazing. Congratulations.

(123) A: He beat his wife up badly. B: He did WHAT? That's terrible. I hope he was reported to the police. 


\section{$9 \quad$ Embedded questions}

(124) A: He asked what I wanted there. How rude of him!

(125) A: Mary wants to know what you would like for dinner. B: I would like some fish.

(126) A: We are wondering when they will come. B: Probably not until late.

(127) A: I don't know whom she will choose. B: Me neither. They are all good.

(128) A: I asked which book she liked. And she said the first one.

(129) A: I don’t know who will arrive first. What do you think? B: I expect Mary will arrive first.

(130) I don't know whether they are coming to the wedding.

(131) I told them where we are going.

(132) They found out whom we voted for.

(133) They asked us when to leave.

(134) I noticed what time Mary got home.

(135) We are wondering whether to call them again.

\section{Counter pairs to embedded questions}

(136) I know that they are coming to the wedding.

(137) I told them we are going home.

(138) They found out that we voted for the opposition.

(139) I noticed that Mary got home at 10pm.

\section{Tag questions}

(140) A: You like coffee, don't you? B: Yes, that's my bad habit.

(141) A: He understands what it means, doesn't he? B: Yes, I think so.

(142) A: You know why there are here, right? B: Yes, I'm afraid so.

(143) A: She is beautiful, isn't she? B: Yes, absolutely.

(144) A: He was great in that movie, wasn't he? B: Well, I didn't really like him in that role.

\section{Question-flagging particle/word}

(145) A: Say, have you ever been to Dubai? B: Not yet.

(146) A: Tell me, do you like it? B: Yes, it's great.

(147) A: Excuse me, are you the new teacher? B: Yes, I am.

(148) A: So, are you going to buy it? B: I don’t know yet. 


\section{Exhaustive questions}

(149) Who all came to the dinner? John, Marry and Steve.

(150) What (all) food do you serve? We have bananas, rice and chapatti.

(151) Which (all) sodas do you have? Coca cola, Fanta and Pepsi.

(152) Which (all) countries have you visited? Only Kenya and Uganda.

\section{Multiple questions}

(153) Context: John came with Mary, and Sue came with Steve.

Q: Who came with whom?

(154) Context: I will bring a salad, John will bring the drinks and Mary will bring a cake.

Q: Who will bring what?

(155) Context: I saw Mary at the movies and John at the library.

Q: Where did you see whom?

(156) Context: I went to Paris in 1980 and to Rome in 1995.

Q: When did you go where?

(157) Context: I am buying the book for John and the game for Mary.

Q: What are you buying for whom?

\section{Imperatives}

(158) A: Give me the milk! B: Give you what (what should I give you)?

(159) A: Stop whistling! B: I should stop what?

(160) A: Don’t break it! B: I should not do what with it?

\section{Wh-element as the only new element in context}

\subsection{Subject}

(161) A: Do you know who saw Juma ? B: No, Who saw him? A: Mary.

(162) A: Do you know what happened? B: No, what happened? A: A waterpipe burst.

(163) A: Do you know who arrived late? B: No, who did/arrived late? A: Mary arrived late.

(164) A: Do you know who wants more cake? B: No, who does/wants more cake? A: The girl in the blue dress.

(165) A: Do you know who will buy the food? B: No, who will (buy the food)? A: Juma.

(166) A: Do you know what damaged the road? B: No what damaged it? A: The rains. 
(167) A: Can you imagine who has fallen asleep? B: No, who has fallen asleep? A: The teacher.

(168) A: Do you know who didn't help to clean the house? B: No, who didn't help to clean the house? A: Hamisi didn't help.

\subsection{Direct Object}

(169) A: Can you imagine who he met at the movies? B: No, who did he meet? A: He met Asha and Juma at the movies.

(170) A: Do you know what they saw in London? B: No, what did they see? A: They saw a football match.

(171) A: Can you imagine what Salma has brought us? B: No, what has she brought? A: Oranges.

(172) A: Do you know who they don't like? B: No, who don't they like? A: They don't like Mary.

\subsection{DOC IO}

(173) A: Do you know what Juma got for Eid /Christmas? B: No, what did he get? A: A new shirt.

(174) A: Do you know who(m) she gave the oranges? B: No, who(m) did she gave the oranges? $\mathrm{B}$ : She gave the oranges to Hassan.

(175) A: Do you know for whom is Mary buying the book? B: No, for whom is she buying it? A: She is buying it for her mother.

(176) A: Can you imagine who we are baking the cake for? B: No, who are you baking the cake for? A: We are baking it for Juma. He is coming to visit tomorrow.

(177) A: Do you know what they are buying the food for? B: No, what are they buying it for? A: They are buying it for the celebration.

(178) A: Do you know who she will teach French to? B: No, who will she teach French to? A: The minister's daughter.

(179) A: Do you know who(m) she hasn't given any cake yet? No, who(m) hasn't she given any cake yet? A: The people sitting on that mat.

\subsection{Others}

(180) A: Can you imagine where I met Mary? B: No, where did you meet her?

A: At the hospital, her neighbour just had a baby.

(181) A: Can you imagine how he fixed it?

(182) B: No, how did he fix it? A: He kicked it. 


\section{Checklist}

- In subject questions, is subject marking possible? Is it obligatory? Are there any changes in the agreement pattern?

- Can a subject be questioned in situ (in preverbal position)? What about expletive constructions? Or embedded questions?

- In object questions, is object marking grammatical? If so, is it obligatory?

- Is there any conjoint/disjoint morphology? Are some tenses impossible in questions (particularly with the wh-word in the immediately post verbal position)?

- Does the $w h$-word appear in a specific position? Is there any flexibility in terms of word order? Do which-questions have a different word order from constituent questions?

- If your language has augments, does the augment appear on the noun in which-questions? Is there an augment(-like element) on the question word?

- Does your language have clitic wh-words? If so are they different from non-clitics in multiple questions?

- Are there any question flagging/introducing words? If so, where do they appear and do they affect the intonation pattern?

- Where do "why" words appear?

- Is there a difference in word order between which-questions and other types of wh-questions for objects (in Double object constructions this will be most visible)?

- Are you sure that you have recorded the right intonation pattern for each question (not a reading intonation? or any other non-natural or noncontext appropriate intonation?)

- Try to use two speakers for question answer pairs if possible. 